European journal of American studies

Summer 2010

\title{
America, the Old?
}

[Keynote lecture, Netherlands American Studies Association, Amsterdam University, 5 March 2010]

James D. Bratt

\section{(2) OpenEdition \\ Journals}

Electronic version

URL: https://journals.openedition.org/ejas/8479

DOI: 10.4000/ejas.8479

ISSN: 1991-9336

Publisher

European Association for American Studies

\section{Electronic reference}

James D. Bratt, "America, the Old?", European journal of American studies [Online], 5-3 | 2010, document 1, Online since 28 June 2010, connection on 08 July 2021. URL: http://journals.openedition.org/ejas/ 8479 ; DOI: https://doi.org/10.4000/ejas.8479

This text was automatically generated on 8 July 2021.

Creative Commons License 


\section{America, the Old?}

[Keynote lecture, Netherlands American Studies Association, Amsterdam University, 5 March 2010]

James D. Bratt

\section{Introduction}

Barack Obama's election to the presidency in 2008 was greeted in most of Europe with joy, or at least relief, an emotion that was shared in a great many precincts in the United States. In both venues a curious mix of language attended these celebrations. A new day had dawned, it was said; the American people had turned a page to give themselves, and the rest of the world, a fresh start. Paradoxically, that meant that the USA would return to being its old, familiar self-a country that played by the rules and acted friendly toward its neighbors, consulting them about mutual interests rather than rampaging around like a rogue elephant.

2 It is the mixed themes of old and new, fresh and familiar, that might be the most illuminating feature of this response. And since associating America with the "new" is altogether predictable, it is the role of the "old" in the mix that merits further scrutiny. Nor should the old be introduced simply as a counter-weight to create an ironic balance; instead, we should consider it fully and in its own right. Thus, the leading question of this essay, a question designed to provoke a new line of reflection across all our disciplines. We can call it history's revenge upon Donald Rumsfeld: on the current scene, is it not America instead of Europe that is "old"? More precisely, what new insights into the United States in its current condition, in its art and literature, its history and politics, issue from our putting on a markedly new pair of glasses and viewing the United States as an aging country?

\section{Ever-New, or Ageing?}

3 That seeing America as old is a new approach can be illustrated from the opening remarks that the subject of my Fulbright project, Abraham Kuyper, made in the 
lectures he delivered at Princeton in 1898, where he had traveled to receive an honorary doctorate. Kuyper began:

A traveler from the old European Continent, disembarking on the shore of this New World. . . [senses that] the old stream of life in which he has been moving [is] almost frost-bound and dull. Here, on American ground, for the first time, he realizes how so many divine potencies, which were hidden away in the bosom of mankind from our very creation but which our old world was incapable of developing, are now beginning to disclose their inward splendor, thus promising a still richer store of surprises for the future. ${ }^{1}$

There is a theological idiom in these phrases that is particular to Kuyper, but otherwise we recognize here a very common sentiment of learned visitors to America. Crévecoeur, Trollope, Tocqueville, Dickens, and Bryce: whatever else they said, with whatever tone, and whatever final evaluations they drew, these observers and a host of others agreed that America was new and different, that on those shores a fundamentally new project was being undertaken with great import for the rest of the world.

They had plenty of Americans at hand to assure them that this was so. In the founding generation, from Ezra Stiles in New England to Thomas Jefferson in Virginia to the forgers of the Great Seal of the United States, it was agreed that the new nation spelled "a new order of the ages." 2 The canonical figures of the mid-nineteenth-century American literary renaissance-Emerson, Whitman, Melville-might have disagreed about other things but agreed that their young and rising nation deserved a whole new literature. ${ }^{3}$ The great politicians have followed along: Lincoln with his "new birth of freedom," Theodore Roosevelt's New Nation, Woodrow Wilson's New Freedom, Franklin Roosevelt's New Deal, John Kennedy's New Frontier-they all share the magic adjective. American Studies as an academic enterprise was launched in the 1950s with major titles evoking the same theme: Virgin Land by Henry Nash Smith, The Machine in the Garden by Leo Marx, this garden presumably being another Eden, wherein, according to R. W. B. Lewis, dwelt The American Adam. The theme, finally, comes down to the present day, as the United States wrestles in the grip of the ideology fixed around the body politic by Ronald Reagan, whose most memorable phrases included the assurance that "it is morning in America."4

6 Ronald Reagan also happened to be the oldest person ever to occupy the Oval Office, and by several accounts his last years therein were marked by incipient senility-and not in the metaphorical but in the clinical sense of the term. That paradox parallels a much larger irony attending the familiar trope of America the new. "America as new" is one of the oldest, most tradition-worn ways to view the United States. To see America as old instead might promise us a fresh start; in any case, it requires new lenses. I am not drawn to this question out of an academic fascination with irony, however, but from a public conversation that has been increasing in volume over the last few years in the United States, a conversation that registers a concern across the spectrum of public opinion that the country has taken a down-turn into the heretofore uncharted territory of constraint and decline. The United States faces, so these observers hold, the prospect of diminished power abroad relative to the rising nations in the world, and a future of reduced possibilities at home spelled by crimped budgets. Its repertoire of politically feasible policies dooms it to orbit in ever-tighter circles around obligations entailed by past commitments, be they noble or mistaken; and its rhetorical repertoire ranges from a president who says that "we can" (and seems to 
mean, we can survive this) to the hosts of right-wing radio whose fulminations amount to one great shriek: this can't be happening to us! Reduced strength, reduced mobility, reduced flexibility, reduced resources, the constraints of the past and the iron cage of memory: if we hear these symptoms described of a person, we would readily (and correctly) conclude that he or she is aging, and not so gracefully.

7 At this point an American audience is conditioned to expect a sudden rhetorical reversal-an assurance that what goes for a person does not necessarily hold for a nation, followed by a recital of the reserves and potential that promise a return to vitality should only this new attitude or that new policy pill be taken. But this essay is not a Viagra commercial. The symptoms of an aging America are real. They may not be the whole picture, but they are major components in it and perhaps the frame besides. I cannot say this is an entirely new phenomenon in American history because, this being an unusual question, we have not generated the historiographical record to tell how new, or recurrent, the United States' present circumstances might be. I would venture as a working hypothesis that, although the U.S. has experienced foreshadowings of this condition before, these have seldom gathered in such a perfect storm and without plausible relief on the horizon. The good news in this situation for academics is that, prodded by circumstances to explore within a new paradigm, we might come up with fresh insights that could be of real service not just to our future careers but to a larger public. The even better news for readers of this journal is that European scholars in American studies are especially well positioned to help in this regard.

Detailing the symptoms of America as ageing could easily absorb the rest of this essay, but as those comments would neither be original nor that suggestive for our scholarly work, I will give a brief sketch under the metaphor of an ageing couple trying to carry on in the old house where they raised their children. The title to this property (the Constitution) is almost 225 years old, and the building, or infrastructure, last renovated sixty years ago, is showing alarming signs of deterioration, as state governors, newspaper columnists, think tanks, and university experts have been pointing out now for a couple decades. Yet the residents are worried about their fixed income and so refuse to undertake the significant short-term borrowing that would yield long-term benefits. This particular couple, as part of the Greatest Generation, profited immensely, along with their own, now middle-aged children, from massive public investments made after World War II; but somewhere in their own middle age they became convinced by Ronald Reagan, himself an abject beneficiary of public largesse, that, in their current situation, "government is not the solution, government is the problem." 5 On the other hand, our couple will spend without stint on anything labeled "security." However much their elected representatives pick over any discretionary social spending, they will pass an annual defense budget of over $\$ 700$ billion with virtually no discussion or objection. Our retirees will also open their wallets for perceived neighborhood safety, particularly to lock up young men of color for non-violent offenses. Thus the American house still stands tall in the global village on certain indices: it controls nearly half of the world'smilitary expenditures, two-thirds of the international weapons trade, and imprisons a higher percentage of its citizens than does any other nation in the world-more than Russia, more than Columbia, more than China, South Africa, Nigeria, more than Belarus. ${ }^{6}$ Never mind that military spending has a lower multiplier effect for economic growth than does infrastructure investment. 
Never mind that a year in jail costs almost as much as a year at Yale. "Millions for the military, sir, but not one cent for welfare!"

Hyper-sensitive though they are about their limited means, as is not unknown among ageing people our American household is still susceptible to scams and risky speculation. Most recently this was a massive real estate bubble whose explosion sent a shock through the entire world economy and has left the home-front struggling for revival. Nor does any widespread recovery appear in the offing. The bankers' downtown penthouses are safe, and the professional neighborhood up the hill is holding on, but along ordinary middle-class streets, values are down and properties foreclosed or abandoned. Consequently the neighbors are all saving against an evil day rather than spending and restarting the economy. Unemployment is near 10 percent; underemployment over 20 percent. $^{7}$ Figures for traditionally vulnerable sectors like young males of color are far worse, but the prospects for white males lacking advanced education are moving in the same direction with no end in sight. ${ }^{8}$ The social dysfunctions that our retired couple have long associated with the black inner-city are -and have been-rising without evident curtailment among rural, working-class, and even middle-class whites. When, in face of this dire prospect, our elderly coupleunable to spend any more on prisons, and reluctant to invest in schools-turns to its political class for leadership, they see the arteriosclerosis of the body politic. The current government has as strong and consolidated a majority as any since the early days of Reagan, but as the travail over the recent, relatively modest reform to the nation's health-care system demonstrated, a filibustering forty senators can block or at least dilute any approach toward the bold changes needed for recovery or sound investment going forward. Not that the representatives among the majority are guiltfree; they too are locked up by commitments made to raise the cash needed to get elected in the first place. ${ }^{9}$

But what is most striking in the present circumstance is our couple's constricted imagination-a constriction predictable at their later stage of life but foreign to their younger years. A trillion dollars of their money went to a war of choice in Iraq on the insistence of old men from the Nixon administration who, among other motives, were determined to exorcise once and for all the memory of defeat in Vietnam. ${ }^{10}$ Tuning in to television, our couple can hear the most popular speaker at the recent convention of self-described Conservatives, Glenn Beck, declare that the entire record of progressive legislation going back to and including Theodore Roosevelt needs to be wiped off the map. ${ }^{11}$ That is, Gilded Age policies for the not so golden years at hand. And why not? Income stratification in the American apartment complex is nearing that of the Gilded Age, and bankers and entrepreneurs of new industries are once again triggering panics and collapses. ${ }^{12}$ Railroads then, hi-tech now; Jay Cooke then, Lehman Brothers now; and J. P. Morgan all the time. If neither the return to Vietnam nor to the Gilded Age goes back far enough, there is the solution posited by Tea Party devotees and some Supreme Court justices: a return to the plain and simple meaning of the original Constitution, as if two centuries had not happened in the meantime. The most popular icon (using the word in its religious sense) of this mentality is the firearm, and the individual's right to bear the same is taken to be the most sacred and inviolable of rights. Miranda rights, the right to a jury trial, even citizenship itself may be stripped from an accused terrorist by state fiat, on this thinking, but not that same person's right to own an assault weapon. Never mind that the successful overturning of oppressive regimes around the world over the last quarter century have all occurred without armed 
uprisings; the American populist today is fixated upon the eighteenth-century frontiersman and his musket. Bold, new, innovative thinkers and can-do confidence? Look not to America, frozen in fear, nostalgia, and bills overdue.

\section{A European Advantage?}

11 In light of this picture, what might European academics do? I suggest that they exploit their advantage as outsiders and let a comparative, pragmatic, and post-imperial sensibility infuse their Americanist researches. Post-imperial, in that Europeans have already lost their empires and have come to terms with that, economically and psychologically, in a constructive way. Remarkably constructive, I would say, in light of so many Americans' inability to imagine a state of less than complete world hegemony without fear and loathing-fear for their own security, and loathing for the specter of weakness such a situation would supposedly spell. We should push the bottom-line question: When were Europeans more prosperous and content, then or now? During their imperial phase or after? I think the answer is clear, and analyzing how your nation came to terms with and prospered after the loss of empire could provide a research agenda for European American studies, as well as a reassuring word to Americans.

12 First of all post-imperial, then, and secondly pragmatic. As Americanists we can appreciate the irony of the fact that, arriving in Europe, this American feels compelled to repeat Lincoln Steffens' dictum upon visiting the Soviet Union in 1921: "I have been over into the future, and it works." Obviously, I repeat this with some trepidation since, in the long run, the USSR did not work, and right now the ripple effect of the crisis in Greek finances throughout the euro-zone augurs fiscal and commercial difficulties of significant dimensions. Still, it is important to list the significant ways that Europe has turned toward a workable future and that America has not. Much of Europe offers an integrated transportation system that is not dedicated to profligate use of fossil fuels for maximum individual convenience; it is embracing, rather than resisting, alternative energy sources; it is not religiously denying climate change; it is providing relatively affordable health care for all on a variety of models; its future citizens as school children perform relatively well on tests of basic competency. Europe's children do lag, admittedly, in reported self-esteem and manifest obesity, but these are good races to lose. So let us for once send those nineteenth-century questions back across the ocean: How do Europeans make it work? From the shambles of World War II, how did they get here? What did they have to give up in the process? What of this was a genuine loss? This last is not a rhetorical question, for American fears that moving forward might cost something precious should not be dismissed out of hand. To glimpse some measure of that cost in a European mirror would be at least instructive, perhaps even comforting.

13 Finally, as these proposals suggest, European Americanists should be comparative. However it might be in other disciplines, this is an encouraging trend in American history right now, signaled by the publication of Thomas Bender's A Nation Among Nations (2006). ${ }^{13}$ European academics' remarkable bi- and tri-lingualism, especially compared with Americans' lingua-phobia, affords a wonderful advantage that they should exploit. With access to a wide range of sources and within a broader frame of reference, they might offer alternative narratives, alternative frameworks of meaning, 
alternative landscapes of imagination. These are the ingredients of vision, and again, just now it is genuinely new vision that the United States lacks.

14 Informed by such a sensibility, what sort of research programs could be undertaken? The most obvious one might be dubbed "comparative slumpology." Critics of the America-as-old trope are quick to point out that the United States has hit the wall before, that it recurrently emits noises of decline and foreboding. Think of Madison Grant's lament over The Passing of the Great Race (1916) and Theodore Roosevelt's concomitant call that the "better" types in American society breed more vigorously lest the lesser sorts run off with the country. These manifestos were accompanied by the greatest outpouring of utopian and dystopian fiction in all of American history, as a small-town agrarian order tried to come to terms imaginatively with an urbanindustrial system. ${ }^{14}$ Further back, no sooner was the War for Independence over than voices elite and popular from across the whole spectrum of Patriot opinion announced that the cause of liberty was being lost-lost forever!-to corruption and conspiracy. Farther back yet, of course, we hear the jeremiad rehearsed so repeatedly as to become a fundamental type of American literature. ${ }^{15}$ These cultural expressions often coincided with economic collapses, or wars, or both. To repeat an earlier question: do the current mood of atrophy and the material forces behind it parallel or significantly diverge from these earlier passages? Programmatic suggestion \#1, then, is to study when and why these slumps occurred, how they were redressed, and what may (or may not) be different about the crisis this time.

15 My second suggestion is one I have already followed, and that is to study the down-turn of movements, be they political, social, or religious. Religion not only happens to be my own focus in American history but, especially in its Protestant evangelical form, offers special insight into the dynamics of revival and decline. I find American religious historians, like American historians more generally, devoted as much as sales-agents to the study of new beginnings, bright possibilities, the launch- and growth-phases of their subjects, to the relative neglect of the inevitable phases of institutionalization or decline. Some of my own work has addressed this bias with respect to the surge of evangelical revivalism in the first third of the nineteenth century, commonly known as the "Second Great Awakening." ${ }^{16}$ What no historian had examined systematically, I discovered upon looking into the subject, was what happened when charisma finally failed, when the fires of the spirit had burned too hot or too long, when the circuitrider dismounted and Charles Finney left the revival trail to become, of all things, a professor of systematic theology. Why was it that the Second Great Awakening did not, as promised, prevent but stoked the Civil War which, whatever else it was, amounted to a consummate failure of the political and cultural formulae to which antebellum evangelicals were dedicated? In the process of reconstructing the down-phase of this story, I discovered it not to be one of unrelieved failure. From the ashes of revivalistic excess emerged a wide array-left, right, and center across the theological spectrumof creative new departures which together, already before the Civil War, set the template of religious options that prevailed in the US until the 1930s. Studies of downsides can uncover the genuinely new.

16 Asking questions about perceived ageing and defeat can also, thirdly, open a new eye upon American regionalism. The most obvious candidate here is the South, as C. Vann Woodward suggested long ago, but there are enough other candidates to make the "afflicted-region" approach more broadly viable. ${ }^{17}$ As a resident-native of Michigan I 
have been watching a whole state suffer catastrophe in slow motion for ten years now. In that time my state lost nearly a quarter million prime auto-manufacturing jobs. Public revenue in Michigan next fiscal year, adjusted for inflation, will approximate one half of what it was just twelve years ago. The city of Detroit has fewer people today than it did ninety years ago. A whole auto industry arose, thrived, and then withered in less than a century, leaving behind rusted plants, shattered office buildings, overextended utilities, and forty square miles (the area of San Francisco) of abandoned space within the city limits..$^{18}$ Anyone who has contemplated the ruins of Ephesus or traced the old circumference of Cahokia will, driving through Detroit (or Cleveland, or Buffalo), suddenly realize what heretofore has been inconceivable to the American mind: it can happen here, to us.

\section{Chances of Revival}

But American history also holds instances of old regions reviving. Consider New England in 1818. By then it was nearly 200 years old and three generations down a lowering trajectory that made it seem destined to become the American equivalent of the Canadian Maritimes: marginal, quaint, and left behind. Worse, to bulwarks of its old order like Timothy Dwight, that year the church in Connecticut lost its official standing. But by 1825 Dwight's disciple Lyman Beecher was exulting that this was the best thing that could ever happen to the cause of religion, as it prompted him to devise the voluntaristic measures that created the "benevolence empire" of a united evangelical front. This empire waxed strongest along the Erie Canal, also completed in 1825, along which streamed the New England diaspora into the upper Midwest. ${ }^{19}$ In this case a bipartisan public works project by New York state coupled with an imaginative breakthrough by people like Beecher helped dramatically reverse the fortunes and influence of an old, once-declining region. We should investigate how the same generations of succession transpired in the now truly old West, in the repeated makeovers of Virginia, etc.

Let me suggest, finally, that some ancient ideological strains can offer promising resources for understanding and dealing with decline. Let us return to evangelical Protestantism as an example. Evangelicalism is dedicated to the new-new birth to start with, and renewed people, fresh glimpses of God, and ceaseless liturgical innovation in its train. But evangelicalism as we know it is 275 years old, dating back to the simultaneous work in the late 1730s of Jonathan Edwards, the brothers Wesley, and George Whitefield on either side of the Atlantic. Its elite forms postulated an early claim upon public life in the young republic, and its populist forms proclaimed that theirs was a new religion (while simultaneously being the very same as apostolic Christianity) perfectly fit for a new nation-a nation and religion alike free from the past, free from tradition, free from old Europe. As Mark Noll has detailed in America's God, evangelicalism was exceptionally well adapted to antebellum America. ${ }^{20}$ Overadapted, as it turned out. Evangelicals could not see beyond their original assumptions and so mostly became captives of the culture instead of the prophetic critics they might have been. I would go further and say that evangelicals have never shaken this molding; that, however much their trappings, technologies, and idioms might have changed since, in their notions of salvation and especially in their social ethic they remain fixed at around 1850, slavery excepted. They remain free-will, free-market 
individualists combining small-group social formation with a conviction that America is God's chosen nation, emphasizing strong personal discipline, the litmus test of which is right sexual behavior.

Anyone who has looked into Sarah Palin's thought and following has seen the noxious ends to which these assumptions can lead: a proprietary claim upon America for just this circle of believers, allegations that political opponents are demon-possessed, a militant Christian Zionism uninformed by the Hebrew prophetic tradition, grave suspicion of big banks-and rejection of any government regulation thereof; deep suspicion of big government-except for a national security apparatus whose total annual budget now exceeds $\$ 1$ trillion; specious allegations about governmentappointed death panels-and praise for torture, rendition, and wars of choice. This, surely, is the sour dead-end of a tradition premised on new life.

But there are evangelicals and there are evangelicals. American evangelicals are also among the most generous private donors of aid to sick, indigent, homeless, and displaced people around the world. They are the Americans most persistently concerned with and effectively alleviating the suffering associated with the AIDS-HIV epidemic in Africa. They show the highest consciousness of any Americans about Darfur. They work not only to provide emergency relief but to build programs of longterm development to be run as soon as possible by indigenous talent. If you're a betting person and you run into a Western-founded health clinic or micro-finance project abroad, put your money on it having Roman Catholic or American evangelical roots. Back home, American evangelicalism has over the last twenty years grown a green wing, mindful that the world is not a commodity but God's creation to be tended and preserved. Younger evangelicals are still as opposed to abortion as are their elders, but are more accepting of same-sex relationships. ${ }^{21}$

\section{Conclusion}

21 My purpose here is not to give a brief for or against American evangelicalism, but to use this particular slice of America that I know best to give what I think is a fair illustration of the potential for good and ill that lies within so many American movements, as in the nation itself. I hope that, over the careers that lie ahead of them, young European Americanists will find a way to bend their teaching and research to ease in some way the difficult transition the United States is undergoing. Here's the Viagra commercial after all: nations and cultures are finally different from persons; the collective condition never has to be terminal.

When Lincoln delivered his first Inaugural Address, the United States faced, mostly unwittingly, the death of its accustomed order and the death of a very great many of its young men. Lincoln hoped, in vain, that the swelling chorus of the Union would drown out the antipathies in his audience. I think less of that Union than did Lincoln; I think it is composed irremediably of sound and toxic strains. Yet it is still worthwhile for us to consider how our work can support the notes arising, in Lincoln's beautiful words, from the better angels of our nature. These do not have to offer re-birth or resurrection, just some light-whether new or old-down a long road. 


\section{NOTES}

1. Abraham Kuyper, Lectures on Calvinism (Grand Rapids: Eerdmans, 1961 [1898]), 9.

2. Ezra Stiles, "The United States Elevated to Glory and Honor: A Sermon . . ." (1783); Thomas Jefferson, Notes on the State of Virginia (1784/1787).

3. This is the theme of two foundational texts in the American Studies movement that was born out of the World War II era: F. O. Matthiessen, American Renaissance (New York: Oxford University Press, 1941); and Perry Miller, The Raven and the Whale (New York: Harcourt, Brace \& World, 1956). The canonical primary text is Emerson's “The American Scholar” (1837).

4. Henry Nash Smith, Virgin Land: The American West as Symbol and Myth (Cambridge: Harvard University Press, 1950); Leo Marx, The Machine in the Garden: Technology and the Pastoral Ideal in America (New York: Oxford University Press, 1964); R. W. B. Lewis, The American Adam: Innocence, Tragedy, and Tradition in the Nineteenth Century (Chicago: University of Chicago Press, 1959). "It's morning again in America" first appeared as the opening line of a television commercial in Reagan's 1984 presidential re-election campaign.

5. The phrase occurs in Reagan's First Inaugural Address and quickly became the motto of his outlook that it remains today. Reagan's father, John Edward Reagan, was saved from alcoholic penury in the Great Depression by a job in the Works Progress Administration of Franklin Roosevelt's New Deal. Reagan himself prospered by the explosive economic and demographic growth of Southern California that was ignited by huge federal spending on war production and infrastructure development there during and after World War II.

6. Current U.S. defense spending amounts to $\$ 708$ billion, including regular appropriations and funding for the wars in Iraq and Afghanistan. Closer analysis reveals a much larger figure for all defense-related spending. Robert Higgs of the conservative Independent Institute conducted such a calculation on the 2007 budget, adding to the Pentagon's funding other relevant categories such as veteran affairs, the Department of Homeland Security, the defense components of the State and Treasury Departments, plus interest charges on all these agencies' proportionate share of the national debt. Higgs computes the total for all U.S. defense spending for fiscal year 2007 to be $\$ 1.028$ trillion. Since these items have been growing at nearly ten percent per year in U.S. budgets, the total today would be well over $\$ 1,250,000,000$. Robert Higgs, "The Trillion Dollar Defense Budget is Already Here," http://www.independent.org/newsroom/article.asp?id=1941. On the U.S. share of international arms sales, see Thom Shankar, "Despite Slump, U.S. Role as Top Arms Supplier Grows," New York Times, 6 September 2009, summarizing the annual report of the Congressional Research Service for 2008. On incarceration in the U.S. and its racial bias, see Michelle Alexander, The New Jim Crow: Mass Incarceration in the Age of Colorblindness (New York: The New Press, 2010); and Glenn C. Loury, Race, Incarceration, and American Values (Cambridge: MIT Press, 2008).

7. April 2010 unemployment figure comes from Bureau of Labor Statistics, U.S. Department of Labor (http://www.bls.gov/eag/eag.us.htm); the underemployment figure comes from the Gallup organization, http://www.gallup.com/poll/128060/improvement-underemployment-stalls-midmay.aspx, both accessed 27 May 2010.

8. Don Peck, "How a New Jobless Era Will Transform America," The Atlantic Magazine,March 2010: http://www.theatlantic.com/magazine/archive/2010/03/how-a-new-jobless-era-will-transformamerica/7919, accessed 27 May 2010.

9. See Robert G. Kaiser, So Damn Much Money: The Triumph of Lobbying and the Corrosion of American Government (New York: Knopf, 2009). His most telling statistics are these: in 1974, the average winning campaign for a U.S. Senate seat cost $\$ 437,000$; in $2006, \$ 7,920,000$. The comparable figures for winning a seat in the House of Representatives are $\$ 56,500$ and $\$ 1,300,000$. 
10. See David Greenberg, "Why Vietnam Haunts the Debate over Iraq," History News Network, 26 April 2004 (http://hnn.us/articles/4779.html).

11. The full text of Beck's keynote speech at the Conservative Political Action Conference on 20 February 2010 is available at http://news.gather.com/viewArticle.action? articleId=281474978060978. Its opening line is, "I hate Woodrow Wilson with everything in me, God bless you." Its screed against "progressivism" as a "disease," a "cancer," and anticonstitutional starts at paragraphs 4 and 5.

12. David Cay Johnston, "Income Gap Is Widening, Data Shows," New York Times, 29 March 2007, analyzing Internal Revenue Service data for 2005.

13. Thomas Bender, A Nation Among Nations: America's Place in World History (New York: Hill \& Wang, 2006). See also Gary W. Reichard and Ted Dixon, eds., America on a World Stage: A Global Approach to U. S. History (Urbana and Chicago: University of Illinois Press, 2008).

14. Frederic Cople Jaher, Doubters and Dissenters: Cataclysmic Thought in America, 1885-1918 (New York: Free Press, 1964).

15. On the Revolutionary era, Gordon S. Wood, "Conspiracy and the Paranoid Style: Causality and Deceit in the Eighteenth Century," William and Mary Quarterly, 3d ser., 39 (1982): 401-41; on the jeremiad, Sacvan Bercovitch, The American Jeremiad (Madison University of Wisconsin Press, 1978).

16. On the dominant syndrome, see Dorothy Ross, "Grand Narrative in American Historical Writing: From Romance to Uncertainty," American Historical Review 100 (June 1995). James D. Bratt, ed., Antirevivalism in Antebellum America: A Collection of Religious Voices (New Brunswick, N.J.: Rutgers University Press, 2006); and James D. Bratt, "Religious Anti-revivalism in Antebellum America," Journal of the Early Republic 24/1 (Spring 2004): 65-106.

17. C. Vann Woodward, The Burden of Southern History, $3^{\text {rd }}$ ed. (Baton Rouge: University of Louisiana Press, 1993); Edward Ayers, et al., eds., All Over the Map: Rethinking American Regions (Baltimore: Johns Hopkins University Press, 1995); William H. Katerberg, Future West: Utopia and Apocalypse in Frontier Science Fiction (Lawrence, Kan.: University Press of Kansas, 2008); Timothy R. Mahoney and Wendy J. Katz, eds., Regionalism and the Humanities (Lincoln: University of Nebraska Press, 2009).

18. Detroit's population was $1,000,000$ in 1920 and is estimated to fall to 800,000 in the 2010 census. Regarding abandoned land in the city limits, see the report by John Gallagher, Detroit Free Press, 15 December 2008, reproduced at http://www.cityfarmer.info/2008/12/23/acres-ofbarren-blocks-offer-chance-to-reinvent-detroit/. On Michigan's public revenue problems, see Citizens Research Council of Michigan, Outline of the Michigan Tax System, July 2008 http:// www.crcmich.org/PUBLICAT/1990s/1999/rpt327d.pdf. On the state's political paralysis, see Peter Luke, "Michigan Economy Needs Investment to Grow," 2 March 2009, MLive.com, http:// blog.mlive.com/peterluke/2009/03/michigan_economy_needs_investm.html. All sites accessed 28 May 2010.

19. Robert Gross, The Minutemen and Their World (New York: Hill and Wang, 1976), is a classic account of New England's stagnation. On the Erie Canal, see Carol Sheriff, The Artificial River: the Erie Canal and the Paradox of Progress, 1817-1862 (New York: Hill and Wang, 1997), and Gerard T. Koeppel, Bond of Union: Building the Erie Canal and the American Empire (Philadelphia: Da Capo Press, 2009). A good study of the resulting cultural ferment is Robert H. Abzug, Cosmos Crumbling: American Reform and the Religious Imagination (New York: Oxford University Press, 1994).

20. Nathan O. Hatch, The Democratization of American Christianity (New Haven: Yale University Press, 1989). Mark A. Noll, America's God: From Jonathan Edwards to Abraham Lincoln (New York: Oxford University Press, 2002).

21. Christian Smith, American Evangelicalism: Embattled and Thriving (Chicago: University of Chicago Press, 1998); Corwin Smidt and James Penning, Evangelicalism: The Next Generation (Grand Rapids: Baker Academic, 2002); Soong-Chan Rah, The Next Evangelicalism: Freeing the Church from 
Western Cultural Captivity (Downers Grove, Ill.: Intervarsity Press, 2009); Bruce Benson and Peter Goodwin Heltzel, eds., Evangelicals and Empire: Christian Alternatives to the Political Status Quo (Grand Rapids: Brazos, 2008); Peter Goodwin Heltzel, Jesus and Justice: Evangelicals, Race, and American Politics (New Haven: Yale University Press, 2009). Readily accessible profiles of evangelical and Roman Catholic activity in sub-Saharan Africa are available in Nicholas D. Kristof's columns in the New York Times; see, inter alia, "Learning from the Sin of Sodom," 27 February 2010, and "A Church Mary Can Love," 17 April 2010.

\section{AUTHOR}

\section{JAMES D. BRATT}

Department of History, Calvin College, Grand Rapids MI,USA (Spring 2010: Fulbright-Dow Distinguished Research Chair, Roosevelt Study Center, Middelburg, the Netherlands) 